\title{
Soil binding properties of mucilage produced by a basidiomycete fungus in a model system
}

\author{
Thecan C. CAESAR-TONTHAT \\ US Department of Agriculture-Agricultural Research Service, Sidney, MT 59270, USA. \\ E-mail: caesart@sidney.ars.usda.gov
}

Received 25 February 2002; accepted 10 July 2002.

\begin{abstract}
A saprophytic, lignin-decomposing basidiomycete fungal isolate (BB1), identified as a member of the russuloid lineage closest to the genus Peniophora, plays a role in soil aggregation and stabilization. In liquid media this fungus secretes large amounts of extracellular materials or mucilage that act as soil binding agents. We investigated the nature of these materials using periodate treatment and lectin cytochemistry, and studied whether or not these materials are involved in soil aggregation. Water stability of artificial fungal amended soil aggregates was destroyed by periodate treatment suggesting that polysaccharides produced by the basidiomycete were involved in soil aggregation. Binding patterns of fluorescently labeled lectins were also investigated to determine specific carbohydrate moieties present in the fungal mucilage. Fluorescently conjugated lectins (Ulex europaeus Agglutinin I and Lotus tetragonolobus lectin) bound to extracellular mucilage indicating that this basidiomycete mucilage contains fucosyl sugar residues. We also demonstrated that water stability of artificial soil aggregates prepared with fungal mycelia pretreated with $\mathrm{L}(-)$ fucose lectins were significantly reduced. This study indicates that fungal-derived material containing fucosyl residues plays a role in soil adhesion.
\end{abstract}

\section{INTRODUCTION}

Tisdall \& Oades (1982) proposed a hierarchical model of soil aggregation processes in which clay particles are bound together into persistent microaggregates (2$20 \mu \mathrm{m}$ diam) by inorganic binding agents consisting of amorphous aluminosilicates, oxides, humic substances, and soil polysaccharides associated with di- or trivalent metal ions. These microaggregates may be bound together with plant debris into larger microaggregates (20-250 $\mu \mathrm{m}$ diam) by temporary binding agents consisting of roots, root hairs, and fungal hyphae. The microaggregates in turn are bound into macroaggregates ( $>250 \mu \mathrm{m}$ diam) which are maintained by transient binding agents in soil including readily decomposable organic materials from plant and microbial origin, the most important of which are polysaccharides and polyuronides.

Most of the extracellular materials present on the surface of the fungal cell are carbohydrate containing molecules. Analysis of fungal cell wall extracts demonstrated that outer layers contain a complex array of

\footnotetext{
1 Abbreviations: Con A, Concanavalin A; DBA, Dolochos biflorus agglutinin; FITC, Fluorescein isothiocyanate; LTL, Lotus tetragonolobus lectin; PNA, peanut agglutinin; PBS, phosphate buffer saline; UEA I, Ulex europaeus agglutinin I; $\mathrm{RCA}_{120}$, Ricinus communis agglutinin I; WGA, wheat germ agglutinin.
}

(glyco) proteins (Aronson 1965), polysaccharides (Barnicki-Garcia 1968, Rosenberger 1976), lipids (lipoproteins) (Weete 1980), and pigments (Arpin \& Fiasson 1971). Although the mechanism of their synthesis and deposition is still poorly understood, it is well recognized that extracellular polysaccharides produced by microbes can have several functions. Besides roles in adhesion (Nicholson 1984), protection against desiccation, freezing, water potential fluctuations (Rudolph \& Crowe 1985), and as a buffer between cells and toxic environments (Gadd 1986), these polysaccharides aggregate soil particles (Mehta et al. 1960, Clapp et al. 1962, Martin 1971, Griffiths \& Burns 1972, Chenu 1989, Wright \& Upadhyaya 1996). The evidence for the role of extracellular polysaccharides produced by fungi in soil aggregation is based on the aggregating action of extracted fungal polysaccharides. Chenu (1989) demonstrated that scleroglucan, a capsular polysaccharide produced by species of Sclerotium, can increase the stability of both kaolinitic and montmorillonitic clays forming organo-mineral networks. Wright \& Upadhyaya (1996) extracted glycoproteinaceous substances named glomalin from soil aggregates.

The fungus isolate (BB1) used in this study was identified as a member of the russuloid clade of Homobasidiomycetes (Hibbett et al. 1997, Hibbett \& Thorn 2001). Phylogenetic analyses of BB1 rDNA identified this 
isolate as a member of russuloid lineage, closest to the genus Peniophora (Caesar-TonThat et al. 2001). Peniophora is a genus of lignocellulose degrading white rot with crust-like fruiting bodies that form on the undersides of dead logs, branches, twigs, and plant residues (Ginns \& Lefevre 1993). Species of Peniophora are mostly found in forest and they not known to occur in soil, but do fruit on plant debris in contact with soil (Ginns \& Lefevre 1993). Isolate BB1 was from surface plant debris agricultural soil and was shown to produce large amounts of water-insoluble mucilage that efficiently bind sandy soil particles (Caesar-TonThat \& Cochran 2000). This isolate also secrete ligninolytic enzymes demonstrated in culture medium containing guaiacol as a substrate (Caesar-TonThat \& Cochran 2000). Nothing is known about the role of lignindegrading basidiomycete fungi in cropland, however their presence in agricultural soils is not surprising because small grains known to contain high amount of lignin, are common agricultural crops in eastern Montana. For example, barley contains 10-12 g lignin $100 \mathrm{~g}$ of stems ${ }^{-1}$ (Cochran 1991). Moreover, management practices such as conservation tillage and no till have become more popular in the Northern Great Plains, resulting in surface accumulation of crop plant residues. In this study, a periodate treatment method developed by Cheshire, Sparling \& Mundie (1983) was used to investigate the carbohydrate nature of the mucilage secreted by BB1 and the implications of these materials in soil aggregation.

In view of the presumptive evidence that polysaccharides secreted by the basidiomycete play a role in soil aggregation, it was desirable to analyze the sugar residues present in the carbohydrates and examine their role in aggregating soil particles. The estimation of surface carbohydrates using traditional biochemical methods has a number of technical problems, since chemical treatment of hyphae is not restricted to their surfaces. Functional entities may be degraded and such methods are not selective enough (Wessels \& Sietsma 1981). Therefore, plant lectins, non-enzymatic proteins with high affinities for mono- and oligosaccharides were utilized to label specific residues on the fungal surface (Erdos 1986). This method has been used successfully with a number of phytopathogenic fungi (Pistole 1981).

As a preliminary step in identifying cell surface receptors for soil binding, this paper reports that of a battery of lectins tested, only those binding to fucosyl residues bound to the cell surface of BB1.

\section{MATERIALS AND METHODS}

\section{Fungal cultures}

Fungal isolation was previously described (CaesarTonThat \& Cochran 2000). The fungus was cultured in potato dextrose broth (Difco Laboratories, Detroit, MI) for 4 weeks at room temperature on a shaker set at $150 \mathrm{rpm}$.

\section{Preparation of artificial fungal-amended aggregates}

Artificial fungal-amended aggregates were prepared as described previously (Caesar-TonThat \& Cochran 2000). Briefly, air-dried soil (14\% clay, $14 \%$ silt, and $72 \%$ sand) was passed through a $0.25 \mathrm{~mm}$ sieve to remove large soil particles before mixing with 4-weekold homogenized mycelia $\left(0.3 \mathrm{~g} \mathrm{~g}^{-1}\right.$ soil). The soil mixture was uniformly wetted with distilled water and air dried in a forced-air oven for $24 \mathrm{~h}$ at $60^{\circ} \mathrm{C}$. The resulting soil cake was manually ground with a pestle into particles of approx. 1-2 mm.

\section{Sodium periodate treatment}

The effects of periodate oxidation on artificial fungal amended soil aggregates were tested according to a method modified from Cheshire et al. (1983). These authors showed that oxidation of soil with periodate increased the disruption of soil aggregates and that the degree of disruption was highly correlated with the residual level of reducing sugars (after hydrolysis). To test the effects of periodate oxidation on fungalamended soil aggregates, $5 \mathrm{~g}$ samples were added to glass beakers ( $100 \mathrm{ml}$ volume) and immersed in $20 \mathrm{ml}$ of sodium chloride solution $(\mathrm{NaCl}, 0.05 \mathrm{M})$ for $24 \mathrm{~h}$ at $22^{\circ}$. Treatment with sodium chloride permits rapid diffusion of periodate ions into the soil aggregates (Clapp \& Emerson 1965b). Soil aggregates were allowed to sediment and the sodium chloride solution was replaced by $20 \mathrm{ml}$ of sodium periodate $\left(\mathrm{NaIO}_{4}, 0.05 \mathrm{M}\right)$ (Sigma, St Louis, MO). Fungal-amended aggregates were incubated for a total period of $12 \mathrm{~h}$ in the sodium periodate solution and they were gently agitated by hand every $15 \mathrm{~min}$. Replicate aliquots were removed at $1 \mathrm{~h}$ intervals. The sodium periodate solution was decanted, replaced by $20 \mathrm{ml}$ of sodium tetraborate $\left(\mathrm{Na}_{2} \mathrm{~B}_{4} \mathrm{O}_{7}, 0.1 \mathrm{M}, \mathrm{pH} 9.6\right.$; Sigma), and incubated for an additional $2 \mathrm{~h}$. Samples were then passed through a $0.25 \mathrm{~mm}$ sieve. The soil aggregate fractions collected on the sieve were oven-dried at $60^{\circ}$ for $24 \mathrm{~h}$ and weighed. Controls were treated with sodium chloride then with distilled water or only with distilled water.

Treatment on fungal mycelia with sodium periodate was intended to demonstrate whether or not extracellular fungal materials contain polysaccharides and polyuronides that are responsible for soil aggregation. Samples of $5 \mathrm{~g}$ of mycelia (wet weight) were treated aseptically and under continuous agitation $(100 \mathrm{rpm})$ with sodium periodate for a total incubation period of $6 \mathrm{~h}$. A concentration of $0.025 \mathrm{M} \mathrm{NaIO}_{4}$, was used to treat fungal mycelia instead of $0.05 \mathrm{~m}$ used to treat fungal-amended soil aggregates. Replicate aliquots were removed at $1 \mathrm{~h}$ intervals. The sodium periodate solution was replaced by sodium tetraborate solution $\left(\mathrm{Na}_{2} \mathrm{~B}_{4} \mathrm{O}_{7}\right.$, $0.1 \mathrm{M}, \mathrm{pH} 9.6$ ) and mycelia were incubated for an additional $2 \mathrm{~h}$. After treatment, mycelia were washed with distilled water through filtration using Whatman paper No. 1, homogenized (Brinkmann Instruments, Westbury, NY) for $30 \mathrm{~s}$, then mixed with soil to generate 


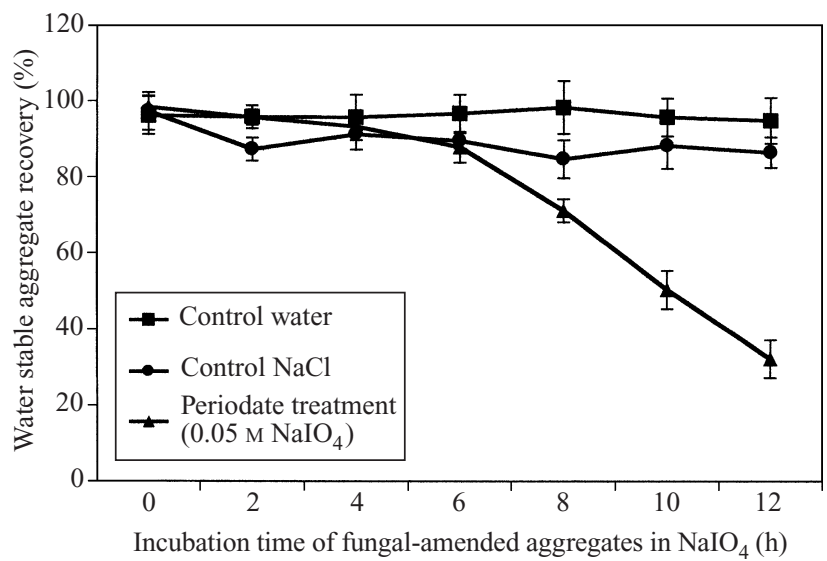

Fig. 1. Effects of periodate treatment on artificial aggregates. Change with time in water stability of fungal-amended aggregates after treatment with: $(\boldsymbol{\Delta}) 0.05 \mathrm{M} \mathrm{NaCl}$ and $0.05 \mathrm{M}$ $\mathrm{NaIO}_{4}$ followed by $0.1 \mathrm{M} \mathrm{Na}_{2} \mathrm{~B}_{4} \mathrm{O}_{7}$ at $\mathrm{pH} 9.6$; ( $)$ distilled water; () $0.05 \mathrm{M} \mathrm{NaCl}$. Bars indicate standard errors of the mean of three replicates.

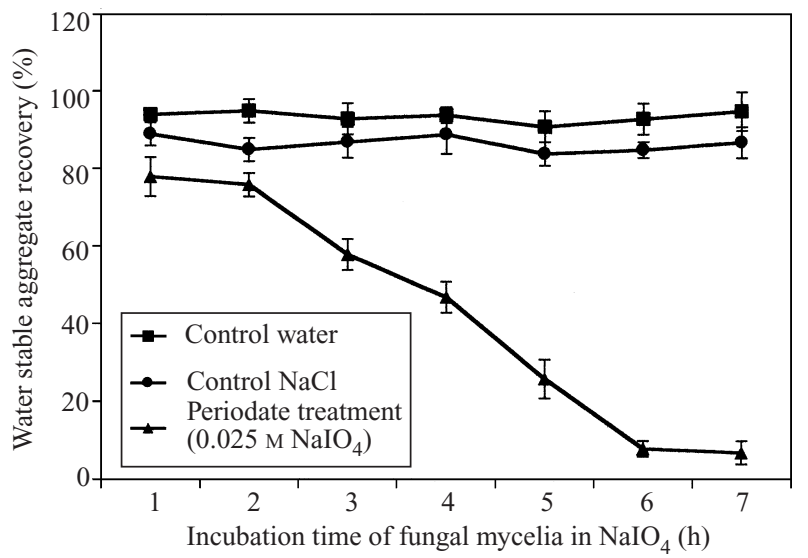

Fig. 2. Change in water stability of soil aggregates prepared with fungal mycelia treated with sodium periodate. (A) $0.05 \mathrm{M} \mathrm{NaCl}$ and $0.025 \mathrm{M} \mathrm{NaIO}_{4}$ followed by $0.1 \mathrm{M} \mathrm{Na}_{2} \mathrm{~B}_{4} \mathrm{O}_{7}$ at $\mathrm{pH} 9.6 ;(\mathbf{\square})$ distilled water; $(\mathbf{O}) 0.05 \mathrm{~m} \mathrm{NaCl}$. Bars indicate standard errors of the mean of three replicates.

artificial aggregates. The mixture was oven-dried at $60^{\circ}$. The dried soil cake was broken into $1-2 \mathrm{~mm}$ aggregates and water stability was determined by a modification according to the procedure of Kemper \& Rosenau (1986). The percentage of water stable aggregate was defined as the portion of the original sample that remained on the sieve. Each determination was made in triplicate.

\section{Staining with lectins}

A set of samples of fungal mycelia were mixed for $1 \mathrm{~h}$ in $3 \%$ formaldehyde in $0.1 \mathrm{~m}$ sodium phosphate buffer (PBS), pH 7.4. To prevent free aldehydes from nonspecifically crosslinking with lectins, mycelia were washed twice with the same buffer, which included 0.05 M glycine (Gilboa-Garber \& Mizrahi 1980) and an additional 2 times with PBS before treatment with lectin compounds. FITC-labeled lectins were obtained from Vector Laboratories (Burlingame, CA, USA) and represent a range of carbohydrate-binding capabilities. The following lectins were used in the present experiments to determine the respective carbohydrates: Con A for $\alpha$-mannose; WGA for $\beta-1,4-N$-acetylglucosamine, SBA for $\alpha-$ and $\beta$ - $N$-acetylgalactosamine, UEA I and LTL for $\alpha$-L-fucose, $\mathrm{RCA}_{120}$ for oligosaccharides ending in galactose, PNA for $\beta-1,3-N$-acetylgalactosamine and $\alpha$ and $\beta$-galactose, DBA for $\alpha-N$-acetylgalactosamine. All lectins were dissolved in PBS at a final concentration of $20 \mathrm{\mu g} \mathrm{ml}^{-1}$. Formaldehyde-fixed mycelia were incubated in lectin solutions for $10 \mathrm{~min}$ to $1 \mathrm{~h}$ at room temperature. They were then washed in PBS and distilled water and mounted on anti-fade medium of 1,4-diazabicyclo [2,2,2]octaine (Sigma) and $2.5 \mathrm{mg} \mathrm{ml}^{-1}$ Glycergel (Dako Corporation, Carpinteria, CA) before viewing. Inhibition by specific hapten sugars was performed to verify specificity of lectin binding. For hapten binding controls, the lectins were bound with their specific sugar. Haptens used were $\mathrm{L}(-)$ fucose for UEA I or LTL, $\propto$-methyl mannoside for ConA, $N, N^{\prime}, N^{\prime \prime}$ triacetyl-chitotriose for WGA, $N$-acetyl-D-galactosamine for SBA, galactose for $\mathrm{RCA}_{120}$ or PNA, and $\mathrm{N}$ acetyl-galactosamine for DBA (Sigma). To prepare controls, $200 \mathrm{~mm}$ of hapten inhibitor was incubated with the lectin solution before it was added to the cells. Material was examined with a Zeiss Axiovert S 100 TV equipped with fluorescent optics. The microscope was fitted with a HBO $50 \mathrm{~W}$ lamp and FITC filter set with exciter filter transmitting at $450-490 \mathrm{~nm}$ and barrier filter transmitting above $520 \mathrm{~nm}$. Photographs were taken on Kodak T Max film rated at 1600 ASA.

To determine whether or not UEA I, LTL, WGA, and ConA can alter the surface mucilage and reduce the capacity of fungal mycelia to aggregate soil particles, mycelia were pretreated for $2 \mathrm{~h}$ at $20^{\circ}$ with nonconjugated lectins at $0.01,0.2$, and $0.4 \mathrm{mg} \mathrm{ml}^{-1}$ in PBS. Mycelia were washed 3 times for 5 min with PBS then they were mixed with soil to form artificial aggregates as described above. Aggregates produced with lectintreated mycelia were tested for their water stability using the wet sieving analysis as described previously (Caesar-TonThat \& Cochran 2000). In the controls, mycelia were treated with lectins that were previously incubated for $30 \mathrm{~min}$ with their respective hapten sugars before mixing with soil to form aggregates. The experiments were repeated three times. The data were analyzed statistically using ANOVA. These analyses were accomplished using Stat View (SAS Institute) (Abacus Concepts 1987).

\section{Low temperature scanning electron microscopy}

Small pieces of mycelia were deposited on an aluminum stub on a thin layer of embedding medium (Tissue-Tek, Torrance, CA). The materials were plunged into nitrogen slush $\left(\leqslant-210^{\circ}\right)$, then the frozen-hydrated tissue was transferred under vacuum to a cryopreparation unit (Oxford CT 1500) attached to a scanning electron microscope (SEM) JEOL JSM-6100 equipped 
with a LaB6 source and turbomolecular pumping. The materials were gold sputter coated to a thickness of approx. 1-2 nm inside the cryopreparation chamber and transferred to the main chamber of the SEM to be analyzed. During sample analysis, the pressure in the SEM chamber was $1 \times 10^{6}$ Torr and the acceleration voltage set at $12 \mathrm{kV}$.

\section{RESULTS}

When soil aggregates artificially prepared with mycelia from the basidiomycete fungal isolate $\mathrm{BB} 1$ were treated with sodium periodate, more than $87.83 \%$ of soil aggregates remained water stable after $6 \mathrm{~h}$ treatment and only $32.17 \%$ of aggregates remained water stable after $12 \mathrm{~h}$ (Fig. 1). Thereafter, the amount of water stable aggregates decreased steadily. Aggregates incubated in water and in $0.05 \mathrm{M} \mathrm{NaCl}$ retained their water stability.

When mycelia were treated with sodium periodate $\left(0.025 \mathrm{M} \mathrm{NaIO}_{4}\right)$ for $1 \mathrm{~h}$ then mixed with soil to generate artificial soil aggregates, $78 \%$ of the soil aggregates remained water stable (Fig. 2). Only $8.2 \%$ of soil aggregates made with mycelia previously treated with sodium periodate for $6 \mathrm{~h}$ were water stable. In control samples, soil aggregates prepared with mycelia treated
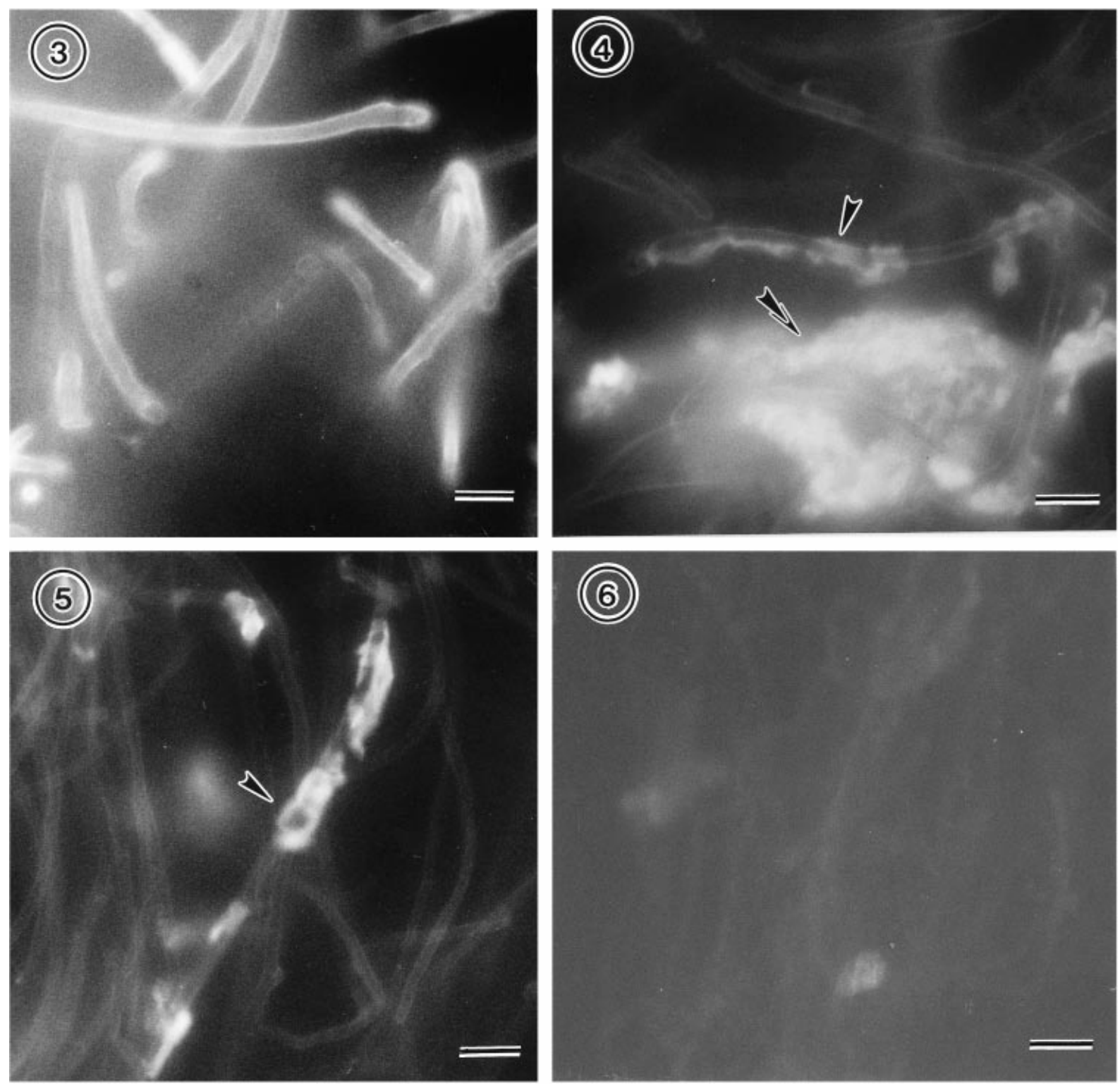

Figs 3-6. Staining of fungal mycelia from basidiomycete isolate BB1 with lectins. Fig. 3. Staining with FITC-WGA. Mycelia bind intensively FITC-WGA resulting in strong fluorescence at the cell wall. Fig. 4. Staining with FITC-UEA I. Low fluorescence is detected along the mycelial cell wall. Intense fluorescence is found on mucilage still attached (single arrow) to or sloughed off (double arrow) from the cell surface. Fig. 5. Staining with FITC-LTL. Fluorescence is detected on mucilage attached to the mycelial cell wall (arrow). Mycelial cell wall is slightly stained. Fig. 6. Staining of fungal mycelia with FITC-UEA I after sodium periodate treatment followed by sodium tetraborate for $6 \mathrm{~h}$. No fluorescence staining is detected. Bars $=5 \mu \mathrm{m}$. 


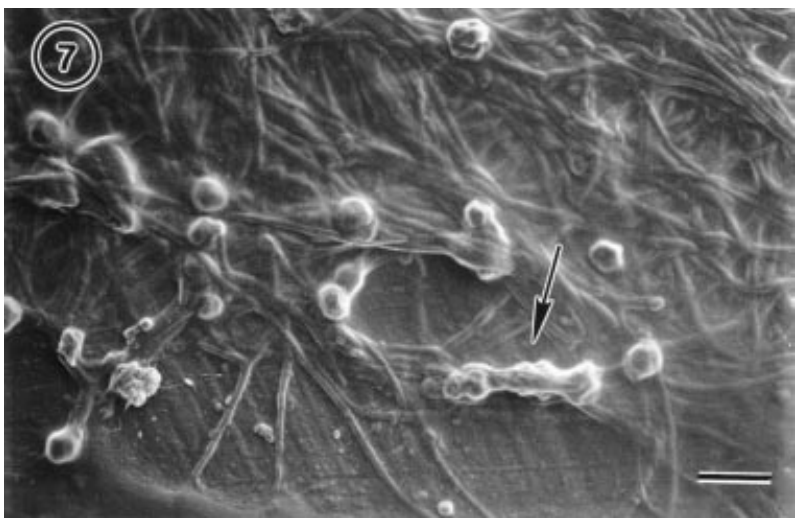

Fig. 7. Low temperature scanning electron micrograph of 4-week-old mycelium showing accumulation of extracellular mucilaginous materials (arrow). Bar $=20 \mu \mathrm{m}$.

water or $0.05 \mathrm{M} \mathrm{NaCl}$ treated mycelia retained their water stability.

Fixation with $3 \%$ formaldehyde did not induce fluorescence. Consequently, all staining was made with formaldehyde fixed materials. Among the FITC-conjugated lectins used in this study to stain fungal mycelia, only staining with FITC-WGA, FITC-UEA I and FITC-LTL resulted in detectable fluorescence (Figs 35). The binding pattern of FITC-WGA differed from FITC-UEA I and FITC-LTL. FITC-WGA bound extensively over the mycelial surface and also throughout the cytoplasm, with distinct areas of bright and low fluorescence (Fig. 3). Unlike FITC-WGA, the fluorescent staining with FITC-UEA I (Fig. 4) and FITCLTL (Fig. 5) was only weakly visible along the cell surface of hyphal cells. However, patches of intense fluorescence were observed randomly in the mycelial preparation. These fluorescent regions presented different shapes, ranging from discrete patches on the cell surface (Figs 4-5, single arrow) to large globules (Fig. 4 , double arrow). Mycelia treated with sodium periodate for $6 \mathrm{~h}$ showed no fluorescence after staining with FITC-UEA (Fig. 6). Because these fluorescent extracellular materials produced by the mycelia were not visible under the bright field or phase contrast optics, scanning electron microscopy was utilized to demonstrate whether or not they could be correlated to some morphological structures. Using low temperature scanning electron microscopy, mycelia showed extracellular materials that were spatially distributed the same way as the materials that fluoresce after FITCUEA or FITC-LTL staining (Fig. 7). There was no binding of FITC-ConA, FITC-SBA, FITC-RCA ${ }_{120}$, FITC-PNA, and FITC-DBA on fungal mycelia. No fluorescence was detected with either FITC-UEAI or FITC-LTL when the lectin was pre-incubated with fucose.

Water stability was compared between artificial soil aggregates amended with fungal mycelia previously treated for $2 \mathrm{~h}$ with non-conjugated lectins (UEA I, LTL, WGA and Con A) at 0.01, 0.2 and $0.4 \mathrm{mg} \mathrm{ml}^{-1}$
Table 1. Effects of modifications of fungal cell surface with lectins on water stability of artificial fungal-amended aggregates.

\begin{tabular}{|c|c|}
\hline Pretreatment & $\begin{array}{l}\text { Water stable } \\
\text { aggregate } \\
\text { recovery }(\%)\end{array}$ \\
\hline Water $\dagger$ & $98.06 \pm 8.53$ \\
\hline Ulex europaeus lectin I (UEA I) & $\begin{array}{l}\text { a93.08 } \pm 10.74 \\
{ }^{\mathrm{p}} 80.74 \pm 8.64^{*} \\
{ }^{\circ} 75.99 \pm 14.70^{* *}\end{array}$ \\
\hline UEA I +0.05 м L $(-)$ fucose & $98.45 \pm 6.95$ \\
\hline Lotus tetragonobolus lectin (LTL) & $\begin{array}{l}89.47 \pm 10.90 \\
{ }^{\mathrm{a}} 82.39 \pm 9.65^{*} \\
71.75 \pm 2.27^{* *}\end{array}$ \\
\hline $\mathrm{LTL}+0.05 \mathrm{\text {мL}(-) \text {fucose }}$ & $95.5 \pm 4.43$ \\
\hline Wheat germ agglutinin (WGA) & 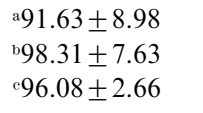 \\
\hline $\begin{array}{l}\text { WGA }+0.02 \text { mu methyl-2-acetomido-2- } \\
\text { deoxy- } \beta \text {-D-glucopyranoside }\end{array}$ & $c 98.06 \pm 3.21$ \\
\hline Concanavalin A (ConA) & 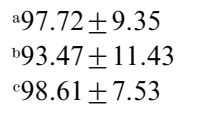 \\
\hline ConA +0.02 mm methyl $\alpha$-mannoside & c97.34 \pm 1.86 \\
\hline
\end{tabular}

$\dagger$ Water is the control for all treatments since pretreatment with the buffer used to prepare lectins (PBS) did not significantly affect aggregation of soil particles. Significantly different from control in water: ${ }^{*} P<0.01 ; * * P<0.001$.

Lectin concentration at ${ }^{\mathrm{a}} 0.01 \mathrm{mg} \mathrm{ml}^{-1} ;{ }^{\mathrm{b}} 0.2 \mathrm{ml} \mathrm{ml}^{-1} ;{ }^{\mathrm{c}} 0.4 \mathrm{mg} \mathrm{ml}^{-1}$.

and the control aggregates amended with water fungal mycelia (Table 1). Significant reduction in water stable aggregate recovery was found in aggregates amended with fungal mycelia pretreated with the $\mathrm{L}(-)$ fucose lectins (UEA I and LTL) at 0.2 and $0.4 \mathrm{mg} \mathrm{m}^{-1}$. Aggregates amended with WGA- and ConA-pretreated mycelia did not result in loss of water aggregate stability. No significant change was found in stability of aggregates prepared with mycelia pretreated with lectins in presence of their appropriate hapten sugars.

\section{DISCUSSION}

The most important property associated with soil polysaccharides is the binding of soil particles into water stable aggregates. Several studies on binding action of soil polysaccharides of humus origin (Mehta et al. 1960, Martin 1971) or from microbial origin in general (Griffiths 1965, Griffiths \& Burns 1972, Chenu 1989, Molope, Grieve \& Page 1987, Robertson, Sarig \& Firestone 1991) have been published. However, so far no work has been reported concerning soil binding of polysaccharides from a specific fungal species. Results of this present study provide further information on soil aggregation by a saprophytic, lignin decomposing russuloid basidiomycete fungus.

Periodate followed by sodium tetraborate treatment destroys long-chain polysaccharides, thus disrupting soil aggregates. This treatment has been used to demon- 
strate the presence of carbohydrates in natural soil aggregates (Mehta et al. 1960, Greenland, Lindstrom \& Quirk 1962, Clapp \& Emerson 1965a, b, Cheshire et al. 1983, 1984, Sparling \& Cheshire 1985, Stefanson 1971, Molope et al. 1987). Periodate oxidizes the glycol groups of the sugar units of the polysaccharides and polyuronides (Bobbit 1956). The oxidized polymers are partially degraded in alkaline solution (Whistler \& BeMiller 1958). Sodium tetraborate treatment is used to complete the degradation of these polymers. We demonstrated that the formation of water stable soil aggregates by the russuloid fungal isolate BB1 is sensitive to periodate treatment indicating the involvement of extracellular basidiomycete-derived polysaccharides in soil aggregation. A $6 \mathrm{~h}$ chemical treatment on fungalamended aggregates was required to induce disruption of the aggregates in water, whereas it needed only $2 \mathrm{~h}$ to treat fungal mycelia with sodium periodate for the aggregates to loose their water stability. Because periodate treatment was processed on dry artificial fungalamended aggregates, air-drying of the aggregates may tighten bridge linkages between polysaccharides and clay in soil as suggested by many authors (Greenland 1956, Emerson, Foster \& Oades 1986), leading to more resistance of the polysaccharides to periodate treatment. When fungal mycelia was treated with periodate before preparation of aggregates, most polysaccharides attached to the cell surface may have been destroyed, resulting in less ability to form resistant bonds during drying.

Fungi are known to secrete polysaccharides with 'adhesive' qualities, which can adsorb soil clay particles (Foster 1981, Chenu 1989) but relatively little is known about the mechanisms by which clays adhere to fungal mycelium. The cell wall of most septate fungi is composed of four intergrading regions: (1) an outermost cell wall layer ( $80-90 \mathrm{~nm}$ thick) of amorphous glucans containing $\beta-1,3$ and $\beta-1,6$ linkages, (2) a glycoprotein network (40-50 nm thick), in which the glucans merge into the protein layer; (3) a discrete protein layer; and (4) an innermost layer (20 nm thick) of chitin microfibrils (Bartnicki-Garcia 1968, Burnett 1976, Fleet \& Phaff 1981). Since fungal mycelium has a net negative charge, it is likely to attract the positively charged edge of clay particles in soil and bring about soil aggregation. The occurrence of hydrogen bonding between the $\beta$ glucan on the outer surface of the fungal cell wall and waters of hydration on the soil clay particle has been suggested as a mechanism of fungal soil clay adsorption (Lavie \& Stotsky 1986).

Using lectins to label specific sugar residues on fungal surfaces (Benhamou 1988, Erdos 1986), we demonstrated that the mucilage secreted by the basidiomycete fungus contains fucosyl sugar residues after staining with FITC conjugated $\mathrm{L}(-)$ fucose binding lectins. Fluorescence of fucosyl sugar residues was detected on materials attached to (Figs 4-5, single arrow) or sloughed off from the fungal cell wall (Fig. 4, double arrows). In contrast to the intense fluorescence of the cell wall observed after staining with FITCWGA indicating the presence of $\mathrm{N}$-acetylglucosamine residues, there was low fluorescence seen on the cell wall stained with FITC conjugated L $(-)$ fucose lectins. $\mathrm{L}(-)$ fucose lectins used in this study were similar in their binding properties; like LTL, UEA I interacts with 6-O-alpha-L-fucosyl- $N$-acetylglucosamine and its related asparagine-linked glycopeptide, but is unable to bind to internal alpha-L-fucosyl units (Goldstein \& Poretz 1986). Deoxyhexoses, including L-fucose (6deoxygalactose) and L-rhamnose, are known to exist in microorganisms (Finch, Hayes \& Stacey 1971, Greenland \& Oades 1975, Cheshire 1979). In fungi, heteropolysaccharides containing fucose have been isolated from basidiomycetes belonging to the Polyporaceae (Bhavanandan, Bouveng \& Lindberg 1964, Fraser, Karaesoni \& Lindberg 1967, Bjorndal \& Wagstrom 1969). Fucose was also found in the extracellular materials produced by a white rot basidiomycete Phlebia radiata (Krcmar et al. 1999). Polysaccharide fractions isolated from Mucorales species were reported to contain glucuronic acids and fucose (Bartnicki-Garcia \& Reyes 1968, Tsuchihashi, Yadomae \& Miyazaki 1983). Fucose moieties were also found in germ tube tip mucilage of the fungal rice blast pathogen Magnaporthe grisea (T. M. Bourett \& R. J. Howard, pers. comm.). In bacteria, rhamnose and fucose were found in the cell membrane of Azospirillum brasilense mucopolysaccharides and polysaccharides (Skvortsov \& Ignatov 1998). Although fucose was reported to be present in plant root mucilage and to have adhesion properties (Hinch \& Clarke 1980, Vermeer \& McCully 1981, Watt et al. $1993)$, the function of fucosyl residues in microorganisms is not well known. Several species of the yeast Candida albicans were shown to contain on their cell wall surface fucosyl and $N$-acetylglucosaminylcontaining residues that were demonstrated to play a role in the adhesion process to exfoliated buccal epithelial cells (Critchley \& Douglas 1987).

We demonstrated that soil aggregation ability of the fungus significantly decreased when fucosyl residues sites were not available for binding soil particles. These results indicate that these sugar residues produced by the basidiomycete fungus and present in the extracellular mucilage exhibit adhesion properties. The ability of soil particles to aggregate to each other could also depend on the integrity of the fungal cell surface components of this basidiomycete fungus. Understanding surface interactions between fungi and soil particulates could provide valuable information for the development of agricultural management techniques that have potential to increase populations of basidiomycete fungi with ability to aggregate soil.

\section{ACKNOWLEDGEMENTS}

The competent technical assistance of April H. Verhasselt is gratefully acknowledged. I also thank Ann C. Kennedy, Robert J. Kremer, R. Greg Thorn, Joan M. Henson, and Timothy M. Bourett for critically reading the manuscript. 


\section{REFERENCES}

Abacus Concepts (1987) Stat View II. Abacus Concepts, Berkeley, CA.

Aronson, J. M. (1965) The Cell Wall. In The Fungi. Vol. I. The Fungal Cell (G. C. Ainsworth \& A. S. Sussman, eds): 49-76. Academic Press, New York.

Arpin, N. \& Fiasson, J.-L. (1971) The pigments of basidiomycetes: their chemotaxonomic interest. In Evolution in the Higher $\mathrm{Ba}$ sidiomycetes (R. H. Petersen, ed.): 63-98. University of Tennessee Press, Knoxville.

Bartnicki-Garcia, S. (1968) Cell wall chemistry, morphology and taxonomy in fungi. Annual Reviews of Microbiology 22: 87-108.

Bartnicki-Garcia, S. \& Reyes, F. (1968) Polyuronides in the cell wall of Mucor rouxii. Biochemistry Biophysics Acta 170: 54-62.

Benhamou, N. (1988) Ultrastructural localization of carbohydrates in the cell walls of two pathogenic fungi: a comparative study. Mycologia 80: 324-337.

Bhavanandan, V. D., Bouveng, M. D. \& Lindberg, B. (1964) Polysaccharides from Polyporus giganteus. Acta Chemistry Scandinavica 18: 504-512.

Bjorndal, H. \& Wagstrom, B. (1969) A heterogalactan elaborated by Polyporus squamosus (Huds.). Acta Chemistry Scandinavica 23 : 3313-3320.

Bobbit, J. M. (1956) Periodate oxidation of carbohydrates. Advances in Carbohydrate Chemistry 11: 1-43.

Burnett, J. H. (1976) Fundamentals of Mycology. Arnold \& Arnold, New York.

Caesar-TonThat, T. C. \& Cochran, V. L. (2000) Soil aggregate stabilization by a saprophytic lignin decomposing basidiomycete fungus. I. Microbiological aspects. Biology and Fertility of Soils 32 : 374-380.

Caesar-TonThat, T. C., Shelver, W. L., Thorn, R. G. \& Cochran, V. L. (2001) Generation of antibodies for soil-aggregating basidiomycete detection as an early indicator of trends in soil quality. Applied Soil Ecology 18: 99-116.

Chenu, C. (1989) Influence of a fungal polysaccharide, scleroglucan, on clay microstructures. Soil Biology Biochemistry 21: 299-305.

Cheshire, M. V. (1979) Nature and Origin of Carbohydrate in Soils. Academic Press, London.

Cheshire, M. V., Sparling, G. P. \& Mundie, C. M. (1983) Effect of periodate treatment on carbohydrate constituents and soil aggregation. Journal of Soil Science 34: 105-112.

Cheshire, M. V., Sparling, G. P. \& Mundie, C. M. (1984) Influence of soil type, crop and air drying on residual carbohydrate content and aggregate stability after treatment with periodate and tetraborate. Plant and Soil 76: 339-347.

Clapp, C. E. \& Emerson, W. W. (1965a) The effect of periodate oxidation on the strength of soil crumbs: I. Quantitative studies. Soil Science Society Proceedings 29: 127-130.

Clapp, C. E. \& Emerson, W. W. (1965b) The effect of periodate oxidation on the strength of soil crumbs: II. Quantitative studies. Soil Science Society Proceedings 29: 130-134.

Clapp, C. E., Davis, R. J. \& Waugaman, S. H. (1962) The effect of rhizobial polysaccharides on aggregate stability. Soil Science Society Proceedings 26: 466-469.

Cochran, V. L. (1991) Decomposition of barley straw in a subarctic soil in the field. Biology and Fertility of Soils 10: 227-232.

Critchley, I. A. \& Douglas, L. J. (1987) Role of glycosides as epithelial cell receptors for Candida albicans. Journal of General Microbiology 133: 637-642.

Emerson, W. W., Foster, R. C. \& Oades, J. M. (1986) Organomineral complexes in relation to soil aggregation and structure. In Interactions of Soil Minerals with Natural Organic and Microbes (P. M. Huang \& M. Schnitzer, eds): 521-548. [Special Publication no. 17.] Soil Science Society of America, Madison.

Erdos, G. W. (1986) Localization of carbohydrate-containing molecules. In Ultrastructure Techniques for Microorganisms (H. C. Aldrich \& W. J. Todd, eds): 399-420. Plenum Press, New York.
Finch, P., Hayes, M. H. B. \& Stacey, M. (1971) The biochemistry in soil polysaccharides. In Soil Biochemistry (A. D. McLaren \& J. Skujins, eds): 257-319. Marcel Dekker, New York.

Fleet, G. H. \& Phaff, H. J. (1981) Fungal glucans - structure and metabolism. In Encyclopedia of Plant physiology (W. Tanner \& F. A. Loewus, eds): 13B: 416-440. New Series. Springer-Verlag, Berlin.

Foster, R. C. (1981) Polysaccharides in soil fabrics. Science 214: 665-667.

Fraser, R. N., Karaesoni, S. \& Lindberg, B. (1967) Polysaccharides elaborated by Polyporus pinicola (Fr.). Acta Chemistry Scandinavica 21: $1783-1789$

Gadd, G. M. (1986) Fungal responses toward heavy metals. In Microbes in Extreme Environments (R. A. Herbert \& G. A. Codd, eds): 83-110. Academic Press, London.

Gilboa-Garber, N. \& Mizrahi, L. (1980) Estimation of nonspecific lectin-mediated staining of glutaraldehyde-fixed cells. Experientia 36: $1416-1417$.

Ginns, J. \& Lefebvre, M. N. L. (1993) Lignicolous corticioid fungi (Basidiomycota) of North America: systematics, distribution and ecology. Mycologia Memoir 19: 1-247.

Goldstein, I. J. \& Poretz, R. D. (1986) Isolation, physicochemical characterization, and carbohydrate-binding specificity of lectins. In The Lectins, Properties, Functions, and Applications in Biology and Medicine (I. E. Liener, N. Sharon \& I. J. Goldstein, eds): 33-214. Academic Press, Orlando.

Greenland, D. J. (1956) The adsorption of sugars by montmorillonite: II. Chemical studies. Journal Soil Science 7: 329-334.

Greenland, D. J., Lindstrom, G. R. \& Quirk, J. P. (1962) Organic materials which stabilize natural soil aggregates. Soil Science Society American Proceedings 26: 366-371.

Greenland, D. J. \& Oades, J. M. (1975) Saccharides. In Soil Components (J. E. Geiseking, ed.): 1: 213-257. Springer-Verlag, New York.

Griffiths, E. (1965) Microorganisms and soil structure. Biological Reviews 40: 129-142.

Griffiths, E. \& Burns, R. G. (1972) Interaction between phenolic substances and microbial polysaccharides in soil aggregation. Plant and Soil 36: 599-612.

Hibbett, D. S. \& Thorn, R. G. (2001) Homobasidiomycetes. In The Mycota. Vol. 7. Systematics and Evolution (D. J. McLaughlin, ed.): 121-168. Springer Verlag, New York.

Hibbett, D. S., Pine, E. M., Langer, E., Langer, G. \& Donoghue, M. J. (1997) Evolution of gilled mushrooms and puffballs inferred from ribosomal DNA sequences. Proceedings of the National Academy of Sciences, USA 94: 12002-1206.

Hinch, J. M. \& Clarke, A. E. (1980) Adhesion of fungal zoospores to root surfaces is mediated by carbohydrate determinants of the root slime. Physiological Plant Pathology 16: 303-307.

Kemper, W. D. \& Rosenau, R. C. (1986) Aggregate stability and size distribution. In Methods of Soil Analysis: physical and mineralogical methods (A. Klute, ed.): 1: 425-442. [SSSA Special Publication no. 9.] American Society of Agronomy, Madison.

Krcmar, P., Novotny, C., Marais, M.-F. \& Joseleau, J.-P. (1999) Structure of extracellular polysaccharide produced by lignindegrading fungus Phlebia radiata in liquid culture. International Journal of Biological Macromolecules 24: 61-64.

Lavie, S. \& Stotsky, G. (1986) Adhesion of the clay minerals Montmorillonite, Kaolinite and Attapulgite reduces respiration of Histoplasma capsulatum. Applied Environmental Microbiology 51: 65-73.

Martin, J. P. (1971) Decomposition and binding action of polysaccharides in soil. Soil Biology and Biochemistry 3: 33-41.

Mehta, N. C., Streuli, H., Muller, M. \& Deuel, H. (1960) Role of polysaccharides in soil aggregation. Journal of Science Food and Agriculture 11: 40-47.

Molope, M. B., Grieve, I. C. \& Page, E. R. (1987) Contributions by fungi and bacteria to aggregate stability in cultivated soils. Journal of Soil Science 38: 71-77. 
Nicholson, R. L. (1984) Adhesion of fungi to the plant cuticle. In Infection Processes in Fungi (D. W. Roberts \& J. R. Aist, eds): 74-89. Rockefeller Foundation, New York.

Pistole, T. G. (1981) Interaction of bacteria and fungi with lectins and lectin-like substances. Annual Reviews of Microbiology 35: 85-112.

Robertson, E. B., Sarig, S. \& Firestone, M. K. (1991) Cover crop management of polysaccharide-mediated aggregation in an orchard soil. Soil Science Society American Journal 55: 734-739.

Rosenberger, R. E. (1976) The cell wall. In The Filamentous Fungi. Vol. 2. Biosynthesis and Metabolism (G. E. Smith \& D. R. Berry, eds): 328-344. Edward Arnold, London.

Rudolph, A. S. \& Crowe, J. H. (1985) Membrane stabilization during freezing: the role of two natural cryoprotectants, trehalose and proline. Cryobiology 22: 367-377.

Skvortsov, I. M. \& Ignatov, W. (1998) Extracellular polysaccharides and polysaccharide-containing biopolymers from Azospirillum species: properties and the possible role in interaction with plant roots. FEMS Microbiological Letters 165: 223-229.

Sparling, G. P. \& Cheshire, M. V. (1985) Effect of periodate oxidation on the polysaccharide content and microaggregate stability on rhizosphere and non-rhizosphere soils. Plant and Soil 88: 113-122.

Stefanson, R. C. (1971) Effect of periodate and pyrophosphate on the seasonal changes in aggregate stabilization. Australian Journal of Soil Research 9: 33-41.

Tisdall, J. M. \& Oades, J. M. (1982) Organic matter and water-stable aggregates in soils. Journal of Soil Science 33: 141-163.
Tsuchihashi, H., Yadomae, T. \& Miyazaki, T. (1983) Structural analysis of the cell-wall D-glucuronans from the fungi Absidia cylindrospora, Mucor mucedo and Rhizopus nigricans. Carbohydrate Research 111: 330-335.

Vermeer, J. \& McCully, M. E. (1981) Fucose in the surface deposits of axenic and field grown roots of Zea mays L. Protoplasma 109: 244-248.

Watt, M., McCully, M. E. \& Jeffree, C. E. (1993) Plant and bacterial mucilage of the maize rhizosphere: comparison of their soil binding properties and histochemistry in a model system. Plant and Soil 151: 151-165.

Weete, J. D. (1984) Spore lipid and surface wax composition and metabolism during germination. In Infection Processes in Fungi (D. W. Roberts \& J. R. Aist, eds): 118-125. Rockefeller Foundation, New York.

Wessels, J. G. \& Sietsma, J. H. (1981) Fungal cell walls - a survey. In Encyclopedia of Plant Physiology. Vol. 2. Plant Carbohydrates (W. Tanner \& F. H. Loewus, eds): 353-385. New series. SpringerVerlag, Heidelberg.

Whistler, R. L. \& BeMiller, J. N. (1958) Alkaline degradation of polysaccharides. Advances in Carbohydrate Chemistry 13: 289-329.

Wright, S. F. \& Upadhyaya, A. (1996) Extraction of an abundant and unusual protein from soil and comparison with hyphal protein of arbuscular mycorrhizal fungi. Soil Science 161: 575-586.

Corresponding Editor: N. P. Money 